\title{
Phenolic and Aroma Composition of White Wines Produced by Prolonged Maceration and Maturation in Wooden Barrels
}

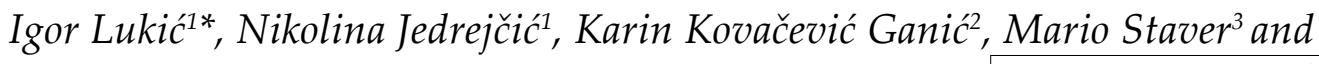 \\ Đordano Peršurić ${ }^{1}$ \\ ${ }^{1}$ Institute of Agriculture and Tourism, Karla Huguesa 8, HR-52440 Poreč, Croatia \\ ${ }^{2}$ University of Zagreb, Faculty of Food Technology and Biotechnology, Pierottijeva 6, HR-10000 Zagreb, Croatia \\ ${ }^{3}$ Polytechnic of Rijeka, Department of Agriculture, Karla Huguesa 6, HR-52440 Poreč, Croatia
}

Received: February 24, 2015

Accepted: July 8, 2015

\begin{abstract}
Summary
To investigate the phenolic and aroma composition of Malvazija istarska (Vitis vinifera L.) white wines produced by an unconventional technology comprising prolonged maceration followed by maturation in wooden barrels, representative samples were subjected to analysis by UV/Vis spectrometry, high-performance liquid chromatography, and gas chromatography-mass spectrometry. When compared to standard wines, the investigated samples contained higher levels of dry extract, volatile acidity, lactic acid, phenols, colour intensity, antioxidant activity, majority of monoterpenes, $\mathrm{C}_{13}$-norisoprenoids, methanol, higher alcohols, ethyl acetate, branched-chain esters and esters of hydroxy and dicarboxylic acids, ethylphenols, furans, and acetals, as well as lower levels of malic acid, $\beta$-damascenone, straight-chain fatty acids, ethyl and acetate esters. It was estimated that maceration had a stronger influence on phenols, and maturation on volatile aromas. Despite different vintages and technological details, the investigated wines showed a relative homogeneity in the composition, representing a clear and distinctive type.
\end{abstract}

Key words: white wine, prolonged maceration, wine maturation, phenols, wine aroma

\section{Introduction}

White wine is most commonly produced with or without short-term, often pre-fermentative maceration, applied mainly to obtain more complex flavour due to the extraction of grape aromas into the must, and to simultaneously keep phenolic compounds at acceptable levels (1-4). To achieve and preserve desirable concentrations of esters with fruity-flowery aroma, fermentation in standard white winemaking is performed by exogenous yeasts in stainless steel tanks, at relatively low temperatures between 12 and $18{ }^{\circ} \mathrm{C}$. Certain alternative practices in white winemaking are also being utilised, such as fermentation by endogenous yeast microflora (5), fermentation and ageing in wooden barrels (6), prolonged maceration during and after fermentation (7), as well as fermentation and ageing in amphorae $(8,9)$. Their effects have been investigated, but independently and sporadically, covering a limited number of analysed components.

Nowadays, in an effort to expand and differentiate their offer and to increase the competitiveness on the market, wine producers in the Mediterranean countries venture into producing different types of wine by technologies that are far from standard. Some of the largest deviations from the standard white winemaking are expressed through various low-intervention approaches and philosophies, such as the production of so-called biodynamic, natural or orange wines, and similar. Wines produced using these approaches, although considered alternative, have become attractive to consumers, and after receiving a lot of attention from wine experts and enthusi- 
asts today are a relevant phenomenon. Such wines are also important from an economic point of view, since they usually achieve medium to high prices, mostly because of low yields and extensive manual work (8).

Such technologies often imply many strict rules, including rigorous selection of grapes picked by hand, limited doses of sulphur dioxide, usage of exclusively indigenous yeasts, maturation on lees until bottling, as well as avoiding yeast nutrients, clarification and filtration, treatments with herbicides, pesticides and other chemicals, and any other correction of physicochemical parameters. Unconventional prolonged maceration during and after fermentation followed by maturation in wooden barrels are almost regularly included, and are the logical choice because they enable implementation of low-intervention principles such as spontaneous fermentation, clarification and stabilisation, as well as treatment with lower doses of sulphur dioxide. In return, these rather atypical practices strongly contribute to the creation of more particular and distinguished products.

It is reasonable to assume that the mentioned combination of techniques result in wines with quite a unique composition, incorporating characteristics of both white and red wines. The effects of maceration known up to date, such as increased amounts of phenols and primary aromas, higher dry extract, and reduced acidity, were determined in experiments with short-term, usually prefermentative white grape mash maceration $(1-4,10)$. Published studies that have investigated prolonged maceration in white winemaking are only a few $(7,11,12)$, and the chemical composition of such wines is almost completely unknown.

The aim of this study is to characterise white wines obtained by the described unconventional technology on the basis of phenolic and aroma compound composition. Wines included were produced in the Istria region of Croatia where, after Italian and Slovenian winemakers who started such trends, a group of innovative producers adopted a number of the previously mentioned principles. Such wines were compared to standard white wines from the same variety. It was considered that the results of this study, although set in the local environment, would provide a significant contribution to the knowledge about global diversity and variability of technological procedures applied in white winemaking, as well as that of the chemical composition of white wine.

\section{Materials and Methods}

\section{Wine samples}

Wine samples selected for this study were produced from the grapes of Malvazija istarska (Vitis vinifera L.). Six samples of wines produced by prolonged maceration during and after fermentation and maturation in wooden barrels, at the peak of their technological maturity, were consigned by local producers together with the largest part of the production documentation. Grape clusters were harvested manually from vines with reduced crop load, and were crushed and mashed without the addition of sulphur dioxide and pectolytic enzymes. During maceration, mashes were fermented with the action of endog- enous yeasts, without the addition of yeast activators, pectolytic enzymes, or any other commercial substrates. All wines underwent spontaneous malolactic fermentation. The majority of samples underwent spontaneous stabilization and clarification during maturation on lees, which lasted until bottling or at least until the first racking. Clarification of one sample was performed with the use of natural fish swimming bladder. Minimum $\mathrm{SO}_{2}$ doses $(<3 \mathrm{~g} / \mathrm{L})$ were added prior to bottling. No correction of any other physicochemical parameter was conducted. Other details on the production of wines obtained by prolonged maceration and maturation in wooden barrels are presented in Table 1

Six samples of standard young Malvazija istarska wines produced by standard white winemaking from grapes harvested in 2010 were collected from the regional market. Basic data on the production collected from the producers through interviews confirmed that standard practices were applied: grape mashes were treated with usual doses of $\mathrm{SO}_{2}(10-15 \mathrm{~g}$ per $100 \mathrm{~kg}$ ) and pectolytic enzymes (2-5 g per $100 \mathrm{~kg})$. Mashes were subjected or not to short-term maceration with a maximum duration of $24 \mathrm{~h}$ at temperatures below $20^{\circ} \mathrm{C}$. Fermentation was conducted with commercial Saccharomyces cerevisiae wine yeasts in stainless steel tanks of various volumes at temperatures between 17 and $19{ }^{\circ} \mathrm{C}$. Commercial yeast activators were utilised. Protein stabilisation (in all wines) and tartrate stabilisation (cold stabilisation of two wines and metatartaric acid stabilisation of three wines) were performed. Six samples of standard Malvazija istarska wines from the market produced in 2009 by standard white winemaking, matured in bottle for a period of one year at variable temperatures between 17 and $20{ }^{\circ} \mathrm{C}$ in the dark, in the minivinification cellar of the Institute of Agriculture and Tourism, Poreč, Croatia, were also included in the investigation. All samples were analysed in June 2011.

\section{Chemical standards and standard solutions}

Pure standards of individual phenolic and volatile aroma compounds were purchased from Merck (Darmstadt, Germany) and Fluka (Buchs, Switzerland). Stock standard solutions were prepared in ethanol. Working standard solutions were prepared by diluting stock standard solutions in synthetic wine.

\section{Analysis of standard physicochemical parameters and organic acids}

Standard physicochemical wine parameters were determined according to the EEC regulation No. 2676/90 (13). Organic acids were identified and quantified using a Varian HPLC system (Varian Inc., Harbour City, CA, USA) with a ProStar 320 solvent delivery module and a ProStar 310 UV-Vis detector. A MetaCarb 87H 300 column (300 $\mathrm{mm} \times 7.8 \mathrm{~mm}$ i.d., $5 \mu \mathrm{m}$ particle size) was used. Samples were diluted ten times with an $11 \%$ ethanol solution, and filtered through $0.45-\mu \mathrm{m}$ nylon filters. Isocratic elution with a $0.0125 \mathrm{M}$ sulphuric acid in deionized water was applied. The flow was $0.7 \mathrm{~mL} / \mathrm{min}$ and the temperature was set at $65{ }^{\circ} \mathrm{C}$. Chromatograms were recorded at 214 $\mathrm{nm}$. Acids were identified by comparing their retention times with those of pure standards. Quantification was 
Table 1. Production parameters of Malvazija istarska wines produced by prolonged maceration during and after fermentation followed by maturation in wooden barrels

\begin{tabular}{|c|c|c|c|c|c|c|}
\hline Production parameter & NMI-1 & NMI-2 & NMI-3 & NMI-4 & NMI-5 & NMI-6 \\
\hline Harvest & 2003 & 2007 & 2007 & 2008 & 2008 & 2009 \\
\hline \multicolumn{7}{|c|}{ Simultaneous maceration and fermentation } \\
\hline Tank/barrel material & oak wood & clay amphora & oak wood & stainless steel & stainless steel & oak wood \\
\hline t/day & 21 & 14 & 16 & 15 & 17 & 20 \\
\hline Cap management & $\mathrm{PD}$ & PD & $\mathrm{PD}, \mathrm{S}$ & $\mathrm{PO}$ & $\mathrm{PD}, \mathrm{S}$ & $\mathrm{PD}, \mathrm{S}$ \\
\hline Temperature $/{ }^{\circ} \mathrm{C}$ & ambient & $18-20$ & $18-20$ & $18-20$ & 27 & $<30$ \\
\hline \multicolumn{7}{|l|}{ Post-fermentative maceration } \\
\hline Tank/barrel material & oak wood & clay amphora & oak wood & - & stainless steel & oak wood \\
\hline t/day & 150 & 2 & 100 & - & 3 & 40 \\
\hline Cap management & - & - & - & - & PD & $\mathrm{PD}, \mathrm{S}$ \\
\hline Temperature $/{ }^{\circ} \mathrm{C}$ & ambient & $20-22$ & $18-20$ & - & 27 & $<30$ \\
\hline \multicolumn{7}{|l|}{ Maturation } \\
\hline Tank/barrel material & oak wood & oak wood & oak wood & oak wood & oak wood & oak wood \\
\hline$t$ (in wooden barrel)/month & 30 & 12 & 30 & 24 & 17 & 12 \\
\hline$t$ (in glass bottle)/month & 54 & 30 & 12 & 6 & 13 & 6 \\
\hline$t($ total $) /$ month & 84 & 42 & 42 & 30 & 30 & 18 \\
\hline
\end{tabular}

NMI-1 to NMI-6=samples of wines produced by prolonged maceration and maturation in six replicates, PD=punching down, $\mathrm{S}=$ stirring, $\mathrm{PO}=$ pumping over

performed using standard calibration curves. The accuracy of the method was checked by the addition of the solution of chemical standards (each acid at $1 \mathrm{~g} / \mathrm{L}$ ) to a wine sample, and it ranged from 97 to $101 \%$ with standard deviation not surpassing $3 \%(N=5)$. Linearity was checked by analysing five different concentrations of standard solutions of each acid ranging from 0.1 to $10 \mathrm{~g} / \mathrm{L}$ and $\mathrm{R}^{2}>0.9999$ was obtained in all cases.

\section{Analysis of phenols, colour parameters and antioxidant activity}

The concentrations of total phenols, total flavonoids, non-anthocyanin flavonoids and total proanthocyanidins, and vanillin index were determined according to Di Stefano et al. (14) using a Cary $50 \mathrm{UV} / \mathrm{Vis}$ spectrophotometer (Varian Inc.). Total phenols were determined using the Folin-Ciocalteu reagent and absorbance measurement at $760 \mathrm{~nm}$ with gallic acid as a calibration standard. The concentration of total and non-anthocyanin flavonoids and proanthocyanidins (high-molecular-mass proanthocyanidins) were measured at 280, 550 and $525 \mathrm{~nm}$, respectively, while vanillin index (flavan-3-ol monomers and oligomers) was determined at $500 \mathrm{~nm}$.

Colour intensity was measured at $420 \mathrm{~nm}$, which corresponds to the brownish hues resulting from chemical and enzymatic browning reactions (7).

Antioxidant activity was determined according to Brand-Williams et al. (15). A reaction between wine antioxidants and $0.094 \mathrm{mM}$ 2-diphenyl-1-picrylhydrazyl (DPPH) in methanol was induced and their antioxidant activity was evaluated by measuring the absorbance at $515 \mathrm{~nm}$ after 60 min at $20^{\circ} \mathrm{C}$ in a water bath. Calibration curves were prepared using a Trolox (6-hydroxy-2,5,7,8-tetramethylchro- man-2-carboxylic acid) reagent solutions.

Phenolic acids and flavan-3-ols were analysed using the already described HPLC system. Samples were diluted and filtered. A ChromSep $\mathrm{C}_{18}$ column $(250 \mathrm{~mm} \times 4.6 \mathrm{~mm}$ i.d., $5 \mu \mathrm{m}$ particle size) with an OmniSpher $5 \mathrm{C}_{18}$ guard column was used. A gradient of solvents A (water/phosphoric acid at 99.5:0.5, by volume) and B (acetonitrile/water/phosphoric acid at 50:49.5:0.5, by volume) was applied as follows: $0-2 \mathrm{~min}, 100 \% \mathrm{~A}$ isocratic; $2-7 \mathrm{~min}, 80 \% \mathrm{~A}$ linear; 7-25 min, $60 \%$ A linear; $25-31 \mathrm{~min}, 60 \%$ A isocratic; 31-40, 0 \% A linear; 40-42 $\mathrm{min}, 0 \%$ A isocratic; 42-47 min, $100 \%$ A linear, and $47-57 \mathrm{~min}, 100 \% \mathrm{~A}$ isocratic. The flow was $1.0 \mathrm{~mL} / \mathrm{min}$ and the temperature was $30{ }^{\circ} \mathrm{C}$. Chromatograms were recorded at $280 \mathrm{~nm}$. Identification was performed by comparing retention times with those of pure standards. Quantification was performed using standard calibration curves. The accuracy of the method was checked by the addition of the solution of chemical standards (each phenol at $10 \mathrm{mg} / \mathrm{L}$ ) to a wine sample, and it ranged from 95 to $99 \%$ with standard deviation not surpassing $5 \%(N=5)$. Linearity was checked by the analysis of standard solutions of each phenol at five different concentrations ranging from 1 to $20 \mathrm{mg} / \mathrm{L}$, and $\mathrm{R}^{2}>0.998$ was obtained in all cases.

\section{Analysis of volatile aroma compounds}

Minor volatile aroma compounds were isolated using headspace solid-phase microextraction (HS-SPME) according to the modified method proposed by Noguerol-Pato et al. (16), and analysed by gas chromatography-mass spectrometry (GC-MS).

SPME fibre holder and 50/30 nm divinylbenzene-carboxen-polydimethylsiloxane (DVB-CAR-PDMS) fibres were 
purchased from Supelco (Bellefonte, PA, USA). All wine samples were adjusted to $11 \%$ of ethanol (by volume). Compounds with high analytical responses were analysed from a 15-fold diluted wine sample. A sample $(4 \mathrm{~mL})$ was placed in a 10-mL glass vial. Internal standard (3-octanol, $30 \mathrm{mg} / \mathrm{L}, 50 \mu \mathrm{L})$ and sodium chloride $(1.4 \mathrm{~g})$ were added. The vial was sealed with a Teflon-faced septum cap, and the sample was preconditioned at $35{ }^{\circ} \mathrm{C}$ for 15 min. Microextraction lasted for $40 \mathrm{~min}$ at $35^{\circ} \mathrm{C}$ with stirring $(1100 \mathrm{rpm})$. For desorption, the fibre was inserted into a GC-MS injector port for $10 \mathrm{~min}$ (3-minute splitless mode).

Identification and quantification of minor volatiles was performed using a Varian 3900 GC coupled with a Varian Saturn 2100T ion trap mass spectrometer (Varian Inc.). The column used was a $60 \mathrm{~m} \times 0.25 \mathrm{~mm}$ i.d., $0.25 \mu \mathrm{m}$ film thickness Rtx-WAX (Restek, Bellefonte, PA, USA). Initial oven temperature was $40^{\circ} \mathrm{C}$, then increased at $2{ }^{\circ} \mathrm{C} /$ min to $240{ }^{\circ} \mathrm{C}$, and then kept at $240^{\circ} \mathrm{C}$ for $10 \mathrm{~min}$. Injector, transfer line and ion trap temperatures were 245, 180 and $120{ }^{\circ} \mathrm{C}$, respectively. Mass spectra were acquired in electron impact mode $(70 \mathrm{eV})$ at $1 \mathrm{scan} / \mathrm{s}$, full scan with a range of $30-450 \mathrm{~m} / \mathrm{z}$. The carrier gas was helium $(1 \mathrm{~mL} /$ min). Identification was performed by comparing retention times and mass spectra with those of pure standards when available, and with mass spectra from NIST05 library (National Institute of Standards and Technology, Gaithersburg, MD, USA). Linear retention indices (relative to $n$-alkanes) were calculated and compared to those from literature. When standards were available, standard calibration curves (based on quantification ions) were constructed. For other compounds semi-quantitative analysis was carried out, and their concentrations were expressed in $\mu \mathrm{g} / \mathrm{L}$ of equivalents of compounds with similar chemical structure for which standards were available, assuming a response factor equal to one.

Major volatiles: acetaldehyde, ethyl acetate, methanol, 1-propanol, 1-butanol, isobutanol and isoamyl alcohol were analysed by a direct injection after distillation on a Varian 3350 GC (Varian Inc.) with a flame-ionisation detector and the same Rtx-WAX column. Initial oven temperature was $40^{\circ} \mathrm{C}$, increased after $4 \mathrm{~min}$ at $5^{\circ} \mathrm{C} / \mathrm{min}$ to 90 ${ }^{\circ} \mathrm{C}$, then at $15{ }^{\circ} \mathrm{C} / \mathrm{min}$ to $235^{\circ} \mathrm{C}$, and then kept for $10 \mathrm{~min}$. Injector and detector temperatures were 160 and $240{ }^{\circ} \mathrm{C}$, respectively. The carrier gas was helium $(1.1 \mathrm{~mL} / \mathrm{min})$. Internal standard was 1-pentanol, with the concentration in the analytical sample of $162.18 \mathrm{mg} / \mathrm{L}$. A volume of $2 \mu \mathrm{L}$ was injected in the split mode (1:20). Compounds were identified by comparing their retention times to those of pure standards. Calibration curves were constructed. The accuracy of the method was checked by the addition of the solution of chemical standards (each compound at 30 $\mathrm{mg} / \mathrm{L}$ ) to a wine sample, and ranged from 95 to $99 \%$ with standard deviation not surpassing $5 \%(N=5)$. Linearity was checked by the analysis of standard solutions of each compound at five different concentrations ranging from 10 to $500 \mathrm{mg} / \mathrm{L}$, and $\mathrm{R}^{2}>0.998$ was obtained in all cases.

Odour activity values (OAV) of volatile aroma compounds were calculated as the quotients of their concentration and the corresponding odour perception threshold from the literature.

\section{Statistical analysis}

All analyses were performed in duplicates, and mean values were used in further data elaboration. Mean values of concentrations and their standard deviations were calculated from six replicates, i.e. six samples of each investigated group of wines. One-way analysis of variance (ANOVA) was carried out using Microsoft Excel (Microsoft, Seattle, WA, USA), and least significant difference (LSD) test was used to compare the mean values at the level of significance of $\mathrm{p}<0.05$.

\section{Results and Discussion}

\section{Physicochemical parameters of wines and concentration of organic acids}

The results of the standard physicochemical analyses are presented in Table 2. As expected, the highest total dry extract was found in the wines produced by prolonged maceration followed by maturation in wooden barrels. Higher volatile acidity in these wines probably resulted from the oxidative conditions during maceration and maturation.

The technology of vinification of these wines included spontaneous malolactic fermentation (Table 1), which explains the lowest malic and the highest lactic acid concentration in these wines (Table 2). Similar can be concluded for the low concentration of citric acid in the wines, since it may also serve as a substrate for the growth of malolactic bacteria.

\section{Phenolic compounds, colour parameters and antioxidant activity of wines}

Concentration of total phenols, flavonoids and proanthocyanidins, and vanillin index

The average concentration of total phenols in white wines produced by standard technology with or without one-year maturation (Table 3) was consistent with the concentrations previously found in standard Malvazija istarska $(4,17)$ and other white wines $(1,18)$.

Wines produced by prolonged maceration and maturation contained significantly higher concentrations of total phenols, which is probably primarily a result of their extraction during maceration. The concentrations of total phenols in these wines were lower than those previously found in white wines produced by prolonged maceration but without maturation $(7,19)$. This is possibly a result of the reduction of phenols during maturation of wines produced by prolonged maceration due to hydrolysis, oxidation, complexation, as well as adsorption on yeast cells and other macromolecules followed by precipitation, which was described by Baiano et al. (8) and Recamales et al. (18). Strong negative correlation found between the concentration of total phenols and the total duration of the maturation of wines produced by prolonged maceration and maturation $(N=6)$, with the correlation coefficient of -0.74 , supports this thesis. Markedly higher concentrations of flavonoids, and especially proanthocyanidins in these wines (Table 3 ) are probably the result of their good solubility in ethanol and extraction from grapes into wine during maceration after finished alcoholic fermentation, as implied in a recent study (20). The extraction of certain 
Table 2. Ranges of standard physicochemical parameters and the concentration of major organic acids in Malvazija istarska wines produced by prolonged maceration during and after fermentation followed by maturation in wooden barrels (NMI), standard white wine production technology followed by maturation in bottle for one year (SMI-1), and standard white wine production technology without maturation (SMI)

\begin{tabular}{|c|c|c|c|c|c|c|}
\hline \multirow{2}{*}{ Parameter } & \multicolumn{2}{|c|}{ NMI } & \multicolumn{2}{|c|}{ SMI-1 } & \multicolumn{2}{|c|}{ SMI } \\
\hline & Mean value \pm S.D. & Range & Mean value \pm S.D. & Range & Mean value \pm S.D. & Range \\
\hline Relative density & $0.991 \pm 0.001$ & $0.989-0.992$ & $0.992 \pm 0.001$ & $0.991-0.994$ & $0.9907 \pm 0.0006$ & $0.9896-0.9911$ \\
\hline$\varphi($ alcohol $) / \%$ & $(14.3 \pm 0.3)^{\mathrm{a}}$ & $13.9-14.8$ & $(12.9 \pm 0.8)^{\mathrm{b}}$ & $11.4-13.7$ & $(13.0 \pm 0.5)^{\mathrm{b}}$ & $12.3-13.6$ \\
\hline$\gamma($ total dry extract $) /(\mathrm{g} / \mathrm{L})$ & $(24.7 \pm 2.7)^{\mathrm{a}}$ & $19.6-27.6$ & $(22.3 \pm 1.1)^{\mathrm{b}}$ & $21.7-24.5$ & $(19.7 \pm 1.0)^{\mathrm{c}}$ & $18.9-21.4$ \\
\hline$\gamma($ reducing sugars $) /(\mathrm{g} / \mathrm{L})$ & $2.4 \pm 0.7$ & $1.3-3.4$ & $2.1 \pm 0.6$ & $1.7-3.2$ & $1.6 \pm 0.4$ & $1.1-2.2$ \\
\hline$\gamma($ ash $) /(\mathrm{g} / \mathrm{L})$ & $2.8 \pm 0.6$ & $2.2-3.8$ & $2.6 \pm 0.4$ & $2.12-3.08$ & $2.5 \pm 0.4$ & $2.0-3.2$ \\
\hline $\mathrm{pH}$ & $3.6 \pm 0.2$ & $3.4-3.8$ & $3.5 \pm 0.1$ & $3.4-3.7$ & $3.6 \pm 0.2$ & $3.4-3.9$ \\
\hline Total acidity/(g/L) & $(5.2 \pm 0.3)^{\mathrm{a}}$ & $4.8-5.6$ & $(5.7 \pm 0.7)^{\mathrm{a}}$ & $4.8-6.6$ & $(4.5 \pm 0.4)^{\mathrm{b}}$ & $4.0-5.0$ \\
\hline Volatile acidity/(g/L) & $(0.7 \pm 0.1)^{\mathrm{a}}$ & $0.6-0.9$ & $(0.24 \pm 0.07)^{\mathrm{b}}$ & $0.2-0.4$ & $(0.4 \pm 0.1)^{\mathrm{b}}$ & $0.2-0.6$ \\
\hline$\gamma\left(\right.$ free $\left.\mathrm{SO}_{2}\right) /(\mathrm{mg} / \mathrm{L})$ & $(9 \pm 2)^{c}$ & $7-14$ & $(15 \pm 5)^{\mathrm{b}}$ & $10-24$ & $(23 \pm 4)^{\mathrm{a}}$ & $19-30$ \\
\hline$\gamma\left(\right.$ total $\left.\mathrm{SO}_{2}\right) /(\mathrm{mg} / \mathrm{L})$ & $(67 \pm 10)^{c}$ & $56-86$ & $(94 \pm 14)^{\mathrm{b}}$ & 79-109 & $(126 \pm 30)^{\mathrm{a}}$ & $89-180$ \\
\hline \multicolumn{7}{|l|}{$\gamma($ organic acids $) /(\mathrm{mg} / \mathrm{L})$} \\
\hline Citric acid & $(164 \pm 100)^{b}$ & $14-281$ & $(278 \pm 94)^{\mathrm{ab}}$ & 149-397 & $(392 \pm 134)^{a}$ & $246-566$ \\
\hline Tartaric acid & $(1718 \pm 210)^{\mathrm{b}}$ & 1511-2053 & $(1615 \pm 181)^{\mathrm{b}}$ & $1325-1819$ & $(2210 \pm 223)^{a}$ & $1825-2496$ \\
\hline Malic acid & $(103 \pm 93)^{c}$ & 0-217 & $(2588 \pm 373)^{\mathrm{a}}$ & 2114-3095 & $(1791 \pm 215)^{b}$ & $1498-2137$ \\
\hline Lactic acid & $(1931 \pm 677)^{\mathrm{a}}$ & $1444-3272$ & $(692 \pm 593)^{\mathrm{b}}$ & 161-1506 & $(333 \pm 33)^{\mathrm{b}}$ & $285-383$ \\
\hline
\end{tabular}

Different superscript lowercase letters in a row present statistically significant differences between mean values at $\mathrm{p}<0.05$ obtained by one-way ANOVA and least significant difference (LSD) test, S.D.=standard deviation $(N=6)$

Table 3. Concentration and ranges of phenols, colour parameters and antioxidant activity of Malvazija istarska wines produced by prolonged maceration during and after fermentation followed by maturation in wooden barrels (NMI), standard white wine production technology followed by maturation in bottle for one year (SMI-1), and standard white wine production technology without maturation (SMI)

\begin{tabular}{|c|c|c|c|c|c|c|}
\hline \multirow{3}{*}{ Parameter } & \multicolumn{6}{|c|}{$\gamma /(\mathrm{mg} / \mathrm{L})$} \\
\hline & \multicolumn{2}{|c|}{ NMI } & \multicolumn{2}{|c|}{ SMI-1 } & \multicolumn{2}{|c|}{ SMI } \\
\hline & Mean value \pm S.D. & Range & Mean value \pm S.D. & Range & Mean value \pm S.D. & Range \\
\hline \multicolumn{7}{|l|}{ Phenols } \\
\hline Total phenols & $(660 \pm 124)^{a}$ & $476-800$ & $(362 \pm 55)^{b}$ & $285-436$ & $(290 \pm 70)^{\mathrm{b}}$ & $220-390$ \\
\hline Total flavonoids & $(386 \pm 107)^{a}$ & $296-585$ & $(90 \pm 51)^{\mathrm{b}}$ & $25-147$ & $(111 \pm 30)^{\mathrm{b}}$ & $78-156$ \\
\hline Proanthocyanidins & $(146 \pm 82)^{\mathrm{a}}$ & $34-281$ & $(32 \pm 19)^{b}$ & $13-68$ & $(11 \pm 5)^{\mathrm{b}}$ & $4-19$ \\
\hline Vanillin index & $(91 \pm 48)^{\mathrm{a}}$ & $19-144$ & $(80 \pm 50)^{\mathrm{a}}$ & $49-180$ & $(15 \pm 5)^{\mathrm{b}}$ & $8-21$ \\
\hline \multicolumn{7}{|l|}{ Hidroxycinnamic acids } \\
\hline Caffeic acid & $11.8 \pm 5.0$ & $8.1-19.0$ & $6.2 \pm 5.5$ & $1.6-16.9$ & $5.3 \pm 4.2$ & $1.4-12.4$ \\
\hline$p$-Coumaric acid & $2.3 \pm 1.0$ & $1.2-3.9$ & $1.3 \pm 0.8$ & $0.7-2.9$ & $1.5 \pm 0.7$ & $0.7-2.7$ \\
\hline Ferulic acid & $(2.2 \pm 1.2)^{\mathrm{a}}$ & $0.6-3.5$ & $(0.7 \pm 0.4)^{\mathrm{b}}$ & $0.2-1.0$ & $(1.0 \pm 0.2)^{\mathrm{b}}$ & $0.8-1.2$ \\
\hline \multicolumn{7}{|l|}{ Hydroxybenzoic acids } \\
\hline Protocatechuic acid & $(14.9 \pm 6.9)^{\mathrm{a}}$ & $3.6-22.2$ & $(3.4 \pm 1.5)^{\mathrm{b}}$ & $1.1-5.7$ & $(6.4 \pm 1.1)^{\mathrm{b}}$ & $5.5-8.6$ \\
\hline Vanillic acid & $(12.3 \pm 11.8)^{\mathrm{a}}$ & $0.0-29.9$ & $(0.8 \pm 0.4)^{\mathrm{b}}$ & $0.4-1.3$ & $(4.7 \pm 2.1)^{\mathrm{ab}}$ & $2.1-7.8$ \\
\hline Syringic acid & $(2.3 \pm 1.3)^{\mathrm{a}}$ & $0.6-4.3$ & $(0.7 \pm 0.4)^{\mathrm{b}}$ & $0.3-1.4$ & $(0.7 \pm 0.7)^{\mathrm{b}}$ & $0.2-1.9$ \\
\hline \multicolumn{7}{|l|}{ Flavan-3-ols } \\
\hline (-)-Epicatechin & $(17.3 \pm 14.2)^{\mathrm{a}}$ & $3.4-42.3$ & $(2.6 \pm 2.6)^{\mathrm{b}}$ & $0.9-7.7$ & $(2.9 \pm 1.7)^{\mathrm{b}}$ & $1.7-6.2$ \\
\hline$(+)$-Catechin & $(31.6 \pm 20.7)^{\mathrm{a}}$ & $1.6-64.8$ & $(7.8 \pm 5.2)^{\mathrm{b}}$ & $3.2-17.6$ & $(7.9 \pm 4.4)^{\mathrm{b}}$ & $3.0-15.8$ \\
\hline Colour intensity $\left(A_{420 \mathrm{~nm}}\right)$ & $(0.40 \pm 0.07)^{a}$ & $0.30-0.52$ & $(0.12 \pm 0.09)^{\mathrm{b}}$ & $0.09-0.14$ & $(0.12 \pm 0.01)^{\mathrm{b}}$ & $0.10-0.13$ \\
\hline $\begin{array}{l}\text { Antioxidant activity } \\
\text { (DPPH' as TE/(mmol/L)) }\end{array}$ & $(4.7 \pm 0.7)^{\mathrm{a}}$ & $4.0-5.8$ & $(1.5 \pm 0.5)^{\mathrm{b}}$ & $0.9-2.2$ & $(0.8 \pm 0.2)^{\mathrm{c}}$ & $0.6-1.2$ \\
\hline
\end{tabular}

Different superscript lowercase letters in a row present statistically significant differences between mean values at $\mathrm{p}<0.05$ obtained by one-way ANOVA and least significant difference (LSD) test, S.D.=standard deviation $(N=6)$. TE=Trolox equivalent 
phenols from the wood of the barrel probably contributed as well.

Concentration of phenolic acids and flavan-3-ols in wine samples

Except maceration, other possible causes of the increase of the concentration of phenolic acids in the wines produced by prolonged maceration and maturation in relation to standard wines produced with or without maturation (Table 3) comprise hydrolysis of corresponding esters and release of their free forms $(18,21)$, as well as their extraction from wood $(22,23)$. Competitive reactions that could have reduced the concentration of phenolic acids include their esterification with tartaric acid to form quinones, hydrolysis, oxidation, and complexation $(7,23)$.

Higher average concentrations of flavan-3-ols in wines produced by prolonged maceration and maturation (Table 3) are in accordance with the findings of a number of authors who noted an increase of flavan-3-ol concentration after a certain maceration period $(1,24)$. However, in this work strong negative correlation between $(+)$-catechin and (-)-epicatechin concentration and total maceration duration was found in macerated wines $(N=6)$, with the correlation coefficients of -0.85 and -0.71 , respectively. Apart from that, $(+)$-catechin content was found to be inversely proportional to total maturation duration $\left(\mathrm{R}^{2}=\right.$ $-0.54)$. On the basis of the results of Ortega et al. (23), it was presumed that the decrease in flavan-3-ol concentration during prolonged maceration and maturation was partially caused by its condensation with acetaldehyde as well as oxidation and condensation with glyoxylic acid.

\section{Colour parameters of wines}

Wines produced by prolonged maceration and matured in wooden barrels had significantly higher colour intensities of brown hues measured at $420 \mathrm{~nm}$ in relation to standard wines produced with or without maturation (Table 3). This was most likely the result of enzymatic as well as oxygen-assisted chemical browning reactions during fermentation, maceration and maturation, as well as the extraction of different compounds from the wood material into the wine, as noted by others $(7,22,23)$.

\section{Antioxidant activity of wines}

Almost six times higher average value of the antioxidant activity found in the wines produced by prolonged maceration and maturation in relation to standard wines produced with or without maturation (Table 3 ) is comparable even with those found in certain red wines (25). High positive correlation coefficients between antioxidant activity and the concentration of total phenols, flavonoids and proanthocyanidins were determined in the wines produced by prolonged maceration and maturation $(N=6)$ : $0.9018,0.9490$ and 0.8741 , respectively, and in standard wines produced without maturation $(N=6)$ : 0.9672, 0.6723 , and 0.9756 , respectively.

\section{Concentration of volatile aroma compounds in the produced wines}

\section{Volatile monoterpenes}

The composition of monoterpenes in standardly produced wines was in a fair agreement with that previously reported for Malvazija istarska young wine $(4,26)$, while in the wines produced by prolonged maceration and maturation it was significantly different (Table 4).

Maceration generally favours the extraction of monoterpenes into must, while during maturation of wine their glycosidic precursors hydrolyse and release free volatile forms (4), which probably contributed to the higher content of linalool in the wines produced by prolonged maceration and maturation (Table 4). It is possible that a part of monoterpene glycosides decreased during fermentation and prolonged maceration due to precipitation, absorption to yeast cells and solids, as well as hydrolysis, as observed by Zoecklein et al. (27), and because of oxidation, acid-catalysed conversions, and evaporation during maturation, as noted by other authors $(28,29)$. In this context, it is interesting to point out high negative correlation coefficients ranging from -0.68 to $-0.78(N=6)$ found between the concentration of the major monoterpenols linalool, nerol, citronellol and geraniol and the duration of maturation of macerated wines.

The highest amount of $\alpha$-terpineol in these wines (Table 4) is in line with previous studies which reported that this compound is formed by oxidation of other monoterpenols and increases during wine ageing (28-30).

\section{$\mathrm{C}_{13}$-norisoprenoids}

The highest concentration of $\beta$-damascenone was found in standard wines, while the highest levels of other $\mathrm{C}_{13}$-norisoprenoids were found in the wines produced by prolonged maceration and maturation (Table 4). This result is in line with the findings by Oliveira et al. (29), who explained a decrease in $\beta$-damascenone concentration during maturation as a consequence of its rapid release from its precursor 3,6,9-trihydroxymegastigma-6,7-diene and reaction with sulphur dioxide. Other authors found a positive correlation of vitispirane, 1,1,6-trimethyl-1,2-dihydronaphthalene (TDN) and actinidol concentration with wine ageing $(29,31,32)$. Except for $\beta$-damascenone and actinidols, the correlation between $\mathrm{C}_{13}$-norisoprenoid concentration and total maturation duration in the wines produced by prolonged maceration and maturation was very strong with the regression coefficients ranging from 0.83 to $0.93(N=6)$. A positive correlation was found between all analysed $C_{13}$-norisoprenoids except $\beta$-damascenone and the duration of maceration of the wines, with the coefficients ranging from 0.74 to $0.95(N=6)$.

\section{Methanol and higher alcohols}

The highest methanol content was found in the wines produced by prolonged maceration and maturation (Table 4), most probably as a result of prolonged maceration. Although high, the levels of methanol in these wines were under the maximum acceptable limit set by the International Organisation of Vine and Wine (OIV) (33).

Elevated concentrations of higher alcohols found in macerated wines are probably the result of the influence of various parameters which were demonstrated to favour their formation: lengthy maceration with aeration, lower partial pressure of $\mathrm{CO}_{2}$ in wooden barrels in relation to stainless steel tanks, higher fermentation temperature, malolactic fermentation, and slow spontaneous clarification (6,34). Câmara et al. (35) partly explained the increase in higher alcohols during ageing in wooden bar- 
Table 4. Concentration and ranges of volatile aroma compounds in Malvazija istarska wines produced by prolonged maceration during and after fermentation followed by maturation in wooden barrels (NMI), standard white wine production technology followed by maturation in bottle for one year (SMI-1), and standard white wine production technology without maturation (SMI)

\begin{tabular}{|c|c|c|c|c|c|c|c|c|}
\hline \multirow{3}{*}{ Compound } & \multirow{3}{*}{ LRI } & \multirow{3}{*}{ ID } & \multicolumn{6}{|c|}{$\gamma /(\mu \mathrm{g} / \mathrm{L})$} \\
\hline & & & \multicolumn{2}{|c|}{ NMI } & \multicolumn{2}{|c|}{ SMI-1 } & \multicolumn{2}{|c|}{ SMI } \\
\hline & & & Mean value \pm S.D. & Range & Mean value \pm S.D. & Range & Mean value \pm S.D. & Range \\
\hline \multicolumn{9}{|l|}{ Monoterpenes } \\
\hline $\begin{array}{l}\text { 2-Ethenyltetrahydro-2,6,6- } \\
\text { trimethyl-2H-pyran }\end{array}$ & 1111 & RI, MS & $(47.1 \pm 32.7)^{\mathrm{a}}$ & $18.1-90.8$ & $(9.7 \pm 4.8)^{\mathrm{b}}$ & $4.8-18.1$ & $(0.5 \pm 1.2)^{\mathrm{b}}$ & $0.0-3.0$ \\
\hline Limonene & 1196 & S, RI, MS & $(26.7 \pm 7.4)^{\mathrm{a}}$ & $17.2-36.8$ & $(13.1 \pm 3.6)^{b}$ & $10.1-18.9$ & $(8.1 \pm 1.9)^{\mathrm{b}}$ & $6.1-11.3$ \\
\hline$\alpha$-Terpinolene & 1281 & RI, MS & $(8.4 \pm 2.8)^{\mathrm{a}}$ & $4.6-12.4$ & $(1.2 \pm 3.0)^{\mathrm{b}}$ & $0.0-7.3$ & $(3.8 \pm 4.5)^{\mathrm{b}}$ & $0.0-9.2$ \\
\hline Terpineol (stereoisomer) & 1446 & MS & $(114.7 \pm 38.2)^{\mathrm{a}}$ & $47.6-150.8$ & $(24.0 \pm 19.3)^{\mathrm{b}}$ & $5.3-60.2$ & $(13.4 \pm 11.0)^{\mathrm{b}}$ & $0.0-26.1$ \\
\hline Nerol oxide & 1467 & RI, MS & $(40.0 \pm 26.9)^{\mathrm{a}}$ & $7.8-74.6$ & $(9.7 \pm 6.4)^{\mathrm{b}}$ & $5.5-22.5$ & $(3.9 \pm 4.1)^{\mathrm{b}}$ & $0.0-11.5$ \\
\hline$\alpha$-Terpinene & 1506 & RI, MS & $(20.7 \pm 7.9)^{\mathrm{a}}$ & $14.1-35.1$ & $(3.6 \pm 0.6)^{b}$ & $2.9-4.3$ & n.d. & - \\
\hline Linalool & 1542 & S, RI, MS & $(37.4 \pm 23.5)^{\mathrm{a}}$ & $13.1-75.2$ & $(20.3 \pm 4.4)^{\mathrm{b}}$ & $16.1-28.5$ & $(15.3 \pm 4.9)^{b}$ & $8.2-22.9$ \\
\hline HO-trienol & 1601 & RI, MS & $22.8 \pm 17.8$ & $11.4-58.1$ & $15.4 \pm 6.2$ & $8.9-25.0$ & $13.2 \pm 5.4$ & $7.4-20.6$ \\
\hline$\alpha$-Terpineol & 1684 & S, RI, MS & $(44.0 \pm 18.0)^{\mathrm{a}}$ & $18.3-61.2$ & $(19.2 \pm 9.0)^{b}$ & $8.6-30.9$ & $(5.3 \pm 2.3)^{\mathrm{c}}$ & $2.0-8.9$ \\
\hline Citronellol & 1758 & S, RI, MS & $2.2 \pm 2.9$ & $0.0-6.4$ & $1.6 \pm 0.4$ & $1.2-2.4$ & $2.0 \pm 1.0$ & $0.5-3.2$ \\
\hline Nerol & 1791 & S, RI, MS & $3.1 \pm 2.0$ & $1.0-5.2$ & $2.2 \pm 1.0$ & $1.1-4.1$ & $4.1 \pm 2.1$ & $1.7-7.9$ \\
\hline Geraniol & 1838 & S, RI, MS & $8.1 \pm 8.6$ & $0.8-23.8$ & $4.9 \pm 2.2$ & $2.7-8.1$ & $6.8 \pm 3.1$ & $3.2-11.8$ \\
\hline \multicolumn{9}{|l|}{$C_{13}$-norisoprenoids } \\
\hline Vitispirane (isomer I) & 1521 & RI, MS & $(37.1 \pm 36.3)^{\mathrm{a}}$ & $5.0-107.0$ & $(5.6 \pm 4.2)^{\mathrm{b}}$ & $1.9-13.7$ & $(1.3 \pm 1.1)^{\mathrm{b}}$ & $0.0-2.6$ \\
\hline $\begin{array}{l}\text { Actinidol ethyl ether } \\
\text { (isomer I) }\end{array}$ & 1690 & RI, MS & $(21.4 \pm 17.4)^{\mathrm{a}}$ & $3.0-49.2$ & $(6.3 \pm 5.6)^{b}$ & $0.8-16.3$ & $(0.3 \pm 0.4)^{\mathrm{b}}$ & $0.0-0.9$ \\
\hline $\begin{array}{l}\text { Actinidol ethyl ether } \\
\text { (isomer II) }\end{array}$ & 1723 & RI, MS & $12.9 \pm 11.5$ & $0.0-31.2$ & $5.2 \pm 4.3$ & $0.8-12.5$ & n.d. & - \\
\hline TDN & 1731 & RI, MS & $12.1 \pm 14.7$ & $1.3-41.3$ & $3.2 \pm 2.9$ & $0.5-8.2$ & $1.8 \pm 0.9$ & $1.0-2.8$ \\
\hline$\beta$-Damascenone & 1809 & RI, MS & $(1.4 \pm 0.9)^{\mathrm{b}}$ & $0.5-2.9$ & $(1.5 \pm 0.2)^{\mathrm{b}}$ & $1.2-1.8$ & $(2.4 \pm 0.6)^{\mathrm{a}}$ & $1.4-3.2$ \\
\hline ТРВ & 1816 & RI, MS & $(3.3 \pm 3.3)^{a}$ & $0.5-9.5$ & $(0.7 \pm 1.0)^{\mathrm{b}}$ & $0.0-2.6$ & n.d. & - \\
\hline Actinidol (isomer I) & 1914 & RI, MS & $(5.6 \pm 4.1)^{\mathrm{a}}$ & $0.0-10.5$ & $(3.3 \pm 2.4)^{\mathrm{ab}}$ & $0.7-6.7$ & $(0.4 \pm 0.9)^{\mathrm{b}}$ & $0.0-2.2$ \\
\hline Actinidol (isomer II) & 1927 & RI, MS & $(8.8 \pm 5.3)^{\mathrm{a}}$ & $1.0-14.5$ & $(5.7 \pm 3.3)^{\mathrm{a}}$ & $1.4-10.4$ & $(0.8 \pm 1.4)^{\mathrm{b}}$ & $0.0-3.4$ \\
\hline \multicolumn{9}{|l|}{$\mathrm{C}_{6}$-alcohols } \\
\hline 1-Hexanol & 1356 & S, RI, MS & $1046.7 \pm 622.5$ & $353.2-1796.9$ & $1200.1 \pm 504.1$ & 581.8-2077.3 & $1021.2 \pm 692.9$ & $385.2-2109.4$ \\
\hline trans-3-Hexen-1-ol & 1361 & S, RI, MS & $(31.6 \pm 17.6)^{\mathrm{b}}$ & $11.9-52.8$ & $(104.2 \pm 62.7)^{\mathrm{a}}$ & $43.2-222.2$ & $(55.4 \pm 20.9)^{\mathrm{b}}$ & $36.1-93.1$ \\
\hline cis-3-Hexen-1-ol & 1379 & S, RI, MS & $49.4 \pm 36.1$ & $12.5-105.9$ & $65.6 \pm 29.1$ & $29.8-117.8$ & $71.7 \pm 21.6$ & $45.4-105.1$ \\
\hline Methanol* $^{*}$ & $<1000$ & S & $(218.8 \pm 23.0)^{a}$ & $180.3-239.2$ & $(87.1 \pm 29.0)^{\mathrm{b}}$ & $62.3-133.2$ & $(79.0 \pm 15.8)^{\mathrm{b}}$ & $60.3-102.5$ \\
\hline \multicolumn{9}{|l|}{ Higher alcohols } \\
\hline 1-Propanol* & 1025 & S, MS & $18.4 \pm 13.8$ & $7.5-44.0$ & $21.0 \pm 6.3$ & $15.9-33.3$ & $15.5 \pm 3.2$ & $11.1-19.3$ \\
\hline Isobutanol $^{*}$ & 1100 & S, RI, MS & $(48.3 \pm 15.8)^{\mathrm{a}}$ & $30.2-75.3$ & $(18.5 \pm 3.3)^{\mathrm{b}}$ & $13.5-23.2$ & $(19.4 \pm 5.0)^{\mathrm{b}}$ & $12.9-26.8$ \\
\hline Isoamyl alcohol* & 1206 & S, RI, MS & $(243.5 \pm 37.6)^{\mathrm{a}}$ & $210.7-301.6$ & $(159.6 \pm 27.1)^{\mathrm{b}}$ & $124.9-192.6$ & $(149.8 \pm 17.0)^{b}$ & $121.8-169.1$ \\
\hline 1-Octen-4-ol & 1535 & RI, MS & $(1.0 \pm 0.5)^{\mathrm{a}}$ & $0.6-1.8$ & $(0.2 \pm 0.2)^{\mathrm{b}}$ & $0.0-0.6$ & n.d. & - \\
\hline 2-Phenylethanol* & 1893 & S, RI, MS & $(40.3 \pm 11.0)^{\mathrm{a}}$ & $26.3-57.8$ & $(26.3 \pm 7.6)^{\mathrm{b}}$ & $16.8-34.9$ & $(16.7 \pm 4.0)^{\mathrm{b}}$ & $12.1-22.4$ \\
\hline \multicolumn{9}{|l|}{ Fatty acids } \\
\hline Isobutyric acid* & 1554 & S, RI, MS & $1.5 \pm 0.9$ & $1.0-3.2$ & $1.2 \pm 0.3$ & $0.8-1.4$ & $1.0 \pm 0.5$ & $0.5-1.9$ \\
\hline Butyric acid* & 1612 & S, RI, MS & $(0.9 \pm 0.2)^{\mathrm{b}}$ & $0.6-1.2$ & $(2.1 \pm 0.5)^{\mathrm{a}}$ & $1.4-3.0$ & $(1.8 \pm 0.3)^{\mathrm{a}}$ & $1.5-2.2$ \\
\hline Hexanoic acid* & 1830 & S, RI, MS & $(1.1 \pm 0.5)^{\mathrm{b}}$ & $0.4-1.7$ & $(5.8 \pm 1.6)^{\mathrm{a}}$ & $3.3-8.1$ & $(5.1 \pm 1.5)^{\mathrm{a}}$ & $3.4-7.5$ \\
\hline Octanoic acid* & 2043 & S, RI, MS & $(0.7 \pm 0.6)^{\mathrm{b}}$ & $0.0-1.6$ & $(6.2 \pm 1.2)^{\mathrm{a}}$ & $4.1-7.6$ & $(5.3 \pm 1.1)^{\mathrm{a}}$ & $3.7-6.9$ \\
\hline Decanoic acid* & 2257 & S, RI, MS & $(0.1 \pm 0.0)^{\mathrm{b}}$ & $0.1-0.2$ & $(1.0 \pm 0.5)^{\mathrm{a}}$ & $0.4-1.6$ & $(1.7 \pm 0.7)^{\mathrm{a}}$ & $0.8-2.6$ \\
\hline Ethyl acetate ${ }^{*}$ & $<1000$ & S, RI & $(75.1 \pm 8.6)^{a}$ & $61.8-85.4$ & $(34.5 \pm 5.1)^{\mathrm{c}}$ & $26.9-41.0$ & $(44.6 \pm 6.4)^{b}$ & $36.2-53.2$ \\
\hline \multicolumn{9}{|l|}{ Ethyl esters of fatty acids } \\
\hline Ethyl butyrate & 1030 & S, RI, MS & $(141.7 \pm 62.6)^{\mathrm{c}}$ & $53.5-247.0$ & $(436.7 \pm 73.8)^{\mathrm{b}}$ & $390.7-580.5$ & $(535.5 \pm 96.9)^{\mathrm{a}}$ & $372.3-636.6$ \\
\hline Ethyl 2-methylbutyrate & 1049 & S, RI, MS & $(12.9 \pm 5.7)^{\mathrm{a}}$ & $8.0-23.4$ & $(4.5 \pm 2.1)^{\mathrm{b}}$ & $1.7-6.9$ & $(2.4 \pm 0.3)^{\mathrm{b}}$ & $2.1-2.7$ \\
\hline Ethyl 3-methylbutyrate & 1065 & S, RI, MS & $(29.2 \pm 17.2)^{\mathrm{a}}$ & $13.1-61.7$ & $(8.9 \pm 2.8)^{\mathrm{ab}}$ & $4.1-12.4$ & $(4.1 \pm 0.9)^{\mathrm{b}}$ & $2.8-5.0$ \\
\hline
\end{tabular}


Table 4. - continued

\begin{tabular}{|c|c|c|c|c|c|c|c|c|}
\hline \multirow{3}{*}{ Compound } & \multirow{3}{*}{ LRI } & \multirow{3}{*}{ ID } & \multicolumn{6}{|c|}{$\gamma /(\mu \mathrm{g} / \mathrm{L})$} \\
\hline & & & \multicolumn{2}{|l|}{ NMI } & \multicolumn{2}{|c|}{ SMI-1 } & \multicolumn{2}{|c|}{ SMI } \\
\hline & & & Mean value \pm S.D. & Range & Mean value $\pm S . D$ & Range & Mean value \pm S.D. & Range \\
\hline Ethyl hexanoate & 1236 & S, RI, MS & $(145.7 \pm 84.3)^{\mathrm{b}}$ & $41.0-266.3$ & $(546.6 \pm 80.4)^{\mathrm{a}}$ & $443.0-679.7$ & $(668.7 \pm 134.8)^{\mathrm{a}}$ & $514.5-875.8$ \\
\hline Ethyl 2-hydroxyisovalerate & 1418 & MS & $1.5 \pm 0.8$ & $0.7-2.9$ & n.d. & - & n.d. & - \\
\hline Ethyl octanoate & 1435 & S, RI, MS & $(128.1 \pm 74.2)^{\mathrm{b}}$ & $42.1-227.0$ & $(804.8 \pm 222.8)^{\mathrm{a}}$ & $528.2-1124.2$ & $(1131.4 \pm 269.7)^{\mathrm{a}}$ & $829.5-1586.9$ \\
\hline Ethyl decanoate & 1637 & S, RI, MS & $(76.9 \pm 56.3)^{c}$ & $31.8-182.9$ & $(493.1 \pm 173.3)^{b}$ & $289.0-764.2$ & $(709.2 \pm 163.5)^{\mathrm{a}}$ & 554.4-981.4 \\
\hline \multicolumn{9}{|l|}{ Acetate esters } \\
\hline Isobutyl acetate & 1009 & S, RI, MS & $(35.7 \pm 6.1)^{b}$ & $27.9-44.9$ & $(40.0 \pm 9.0)^{\mathrm{b}}$ & $26.2-53.1$ & $(79.3 \pm 37.4)^{\mathrm{a}}$ & $32.5-132.9$ \\
\hline Isoamyl acetate* & 1120 & S, RI, MS & $(0.1 \pm 0.1)^{c}$ & $0.0-0.3$ & $(1.8 \pm 0.3)^{\mathrm{b}}$ & $1.3-2.3$ & $(3.9 \pm 1.4)^{\mathrm{a}}$ & $2.1-5.3$ \\
\hline Hexyl acetate & 1272 & S, RI, MS & $(2.2 \pm 1.8)^{\mathrm{c}}$ & $1.0-5.9$ & $(49.0 \pm 11.9)^{\mathrm{b}}$ & $30.2-62.0$ & $(126.2 \pm 41.2)^{a}$ & $76.8-164.1$ \\
\hline 2-Phenethyl acetate* & 1803 & S, RI, MS & $(0.2 \pm 0.1)^{\mathrm{c}}$ & $0.0-0.3$ & $(1.3 \pm 0.1)^{\mathrm{b}}$ & $1.3-1.4$ & $(2.0 \pm 0.4)^{\mathrm{a}}$ & $1.4-2.4$ \\
\hline \multicolumn{9}{|c|}{ Esters of hydroxy and dicarboxylic acids } \\
\hline Ethyl lactate* & 1341 & S, RI, MS & $(143.9 \pm 44.3)^{\mathrm{a}}$ & $90.1-192.9$ & $(20.7 \pm 7.9)^{\mathrm{b}}$ & $8.1-32.0$ & $(12.4 \pm 6.7)^{b}$ & $6.6-23.1$ \\
\hline Isoamyl lactate & 1561 & RI, MS & $(461.4 \pm 89.9)^{\mathrm{a}}$ & $362.3-616.8$ & $(134.3 \pm 25.3)^{\mathrm{b}}$ & $108.7-175.3$ & $(157.4 \pm 25.8)^{b}$ & $122.8-191.6$ \\
\hline Diethyl malonate & 1570 & RI, MS & $(38.5 \pm 32.9)^{a}$ & $0.0-79.9$ & $(34.9 \pm 27.2)^{\mathrm{a}}$ & $14.0-85.7$ & $(1.6 \pm 3.9)^{\mathrm{b}}$ & $0.0-9.5$ \\
\hline Ethyl methyl succinate & 1622 & RI, MS & $(123.3 \pm 31.7)^{\mathrm{a}}$ & $89.8-158.7$ & $(16.8 \pm 14.3)^{\mathrm{b}}$ & $0.0-35.1$ & $(1.9 \pm 4.7)^{\mathrm{b}}$ & $0.0-11.4$ \\
\hline Diethyl succinate* & 1667 & S, RI, MS & $(13.9 \pm 4.1)^{\mathrm{a}}$ & $8.3-18.2$ & $(3.1 \pm 0.7)^{\mathrm{b}}$ & $2.4-4.2$ & $(0.8 \pm 0.8)^{\mathrm{b}}$ & $0.2-2.4$ \\
\hline Acetaldehyde* $^{*}$ & $<1000$ & S & $45.5 \pm 32.0$ & $15.1-98.6$ & $92.4 \pm 61.4$ & $27.6-169.6$ & $40.9 \pm 4.6$ & $34.9-46.9$ \\
\hline \multicolumn{9}{|l|}{ Volatile phenols } \\
\hline 4-Ethylguaiacol & 2009 & RI, MS & $(445.7 \pm 392.2)^{\mathrm{a}}$ & $25.5-916.5$ & $(2.2 \pm 3.0)^{\mathrm{b}}$ & $0.0-7.7$ & $(6.3 \pm 15.5)^{\mathrm{b}}$ & $0.0-38.0$ \\
\hline 4-Propylguaiacol & 2088 & RI, MS & $43.8 \pm 45.0$ & $0.0-124.9$ & n.d. & - & n.d. & - \\
\hline Eugenol & 2148 & S, RI, MS & $13.0 \pm 12.2$ & $3.9-37.0$ & n.d. & - & n.d. & - \\
\hline 4-Ethylphenol & 2156 & S, RI, MS & $(119.0 \pm 127.8)^{a}$ & $3.3-332.0$ & $(0.7 \pm 0.3)^{\mathrm{b}}$ & $0.3-1.0$ & $(0.8 \pm 0.6)^{b}$ & $0.2-1.9$ \\
\hline 4-Vinylguaiacol & 2175 & RI, MS & $117.1 \pm 73.4$ & $44.3-208.1$ & $284.9 \pm 209.9$ & $130.5-698.7$ & $449.2 \pm 494.9$ & $124.5-1426.9$ \\
\hline 4-Vinylphenol & 2366 & RI, MS & $83.4 \pm 102.3$ & $0.0-250.1$ & $84.3 \pm 98.4$ & $0.0-270.3$ & $190.8 \pm 211.4$ & $0.0-572.6$ \\
\hline \multicolumn{9}{|l|}{ Benzenoids } \\
\hline Styrene & 1253 & RI, MS & $(5.9 \pm 2.0)^{\mathrm{a}}$ & $3.6-8.9$ & $(1.7 \pm 0.6)^{\mathrm{b}}$ & $0.8-2.5$ & $(7.2 \pm 2.7)^{\mathrm{a}}$ & $3.3-10.5$ \\
\hline Benzaldehyde & 1508 & S, RI, MS & $(4.2 \pm 2.7)^{\mathrm{ab}}$ & $0.7-8.6$ & $(0.5 \pm 0.4)^{\mathrm{b}}$ & $0.0-1.1$ & $(14.0 \pm 14.0)^{\mathrm{a}}$ & $2.3-39.8$ \\
\hline Methyl salicylate & 1759 & RI, MS & $45.5 \pm 60.3$ & $9.0-164.7$ & $9.2 \pm 4.4$ & $5.6-17.7$ & $19.0 \pm 7.5$ & $10.9-29.2$ \\
\hline Ethyl benzeneacetate & 1773 & RI, MS & $(9.1 \pm 2.3)^{\mathrm{a}}$ & $6.1-12.6$ & $(4.6 \pm 2.0)^{\mathrm{b}}$ & $2.0-7.2$ & $(1.8 \pm 0.7)^{\mathrm{c}}$ & $1.0-3.0$ \\
\hline 2-Ethoxybenzyl alcohol & 1922 & MS & $1.8 \pm 4.4$ & $0.00-10.77$ & n.d. & - & n.d. & - \\
\hline Ethyl cinnamate & 2111 & S, RI, MS & $0.5 \pm 0.4$ & $0.3-1.2$ & $0.4 \pm 0.1$ & $0.3-0.5$ & $0.6 \pm 0.3$ & $0.3-1.1$ \\
\hline \multicolumn{9}{|l|}{ Furans } \\
\hline Furfuryl ether & 1284 & MS & $(248.0 \pm 260.7)^{\mathrm{a}}$ & $19.9-677.1$ & $1.1 \pm 1.2)^{\mathrm{b}}$ & $0.0-3.0$ & n.d. & - \\
\hline Furfural & 1451 & RI, MS & $(2.1 \pm 0.6)^{\mathrm{a}}$ & $1.3-2.6$ & $(0.6 \pm 0.3)^{\mathrm{b}}$ & $0.3-1.1$ & $(0.1 \pm 0.1)^{\mathrm{b}}$ & $0.0-0.3$ \\
\hline 2-Acetylfuran & 1491 & RI, MS & $18.8 \pm 6.3$ & $9.1-27.2$ & n.d. & - & n.d. & - \\
\hline 5-Methylfurfural & 1556 & RI, MS & $(95.5 \pm 89.7)^{a}$ & $11.2-262.8$ & $(1.0 \pm 1.2)^{\mathrm{b}}$ & $0.0-2.5$ & $(0.4 \pm 1.0)^{\mathrm{b}}$ & $0.0-2.5$ \\
\hline Ethyl 2-furoate & 1609 & RI, MS & $29.0 \pm 17.8$ & $6.6-53.4$ & $18.7 \pm 12.2$ & $5.8-40.3$ & $10.2 \pm 8.3$ & $0.0-23.5$ \\
\hline Furfuryl alcohol & 1644 & RI, MS & $59.8 \pm 42.8$ & $4.3-109.1$ & n.d. & - & n.d. & - \\
\hline \multicolumn{9}{|l|}{ Lactones } \\
\hline$\gamma$-Butyrolactone & 1606 & RI, MS & $(163.1 \pm 29.2)^{\mathrm{a}}$ & $130.8-213.5$ & $(57.9 \pm 11.3)^{\mathrm{b}}$ & $41.6-71.3$ & $(58.9 \pm 18.4)^{\mathrm{b}}$ & $39.1-92.0$ \\
\hline trans-Oak lactone & 1868 & RI, MS & $164.7 \pm 110.1$ & $77.8-376.9$ & n.d. & - & n.d. & - \\
\hline cis-Oak lactone & 1938 & RI, MS & $604.6 \pm 617.9$ & 152.1-1793.2 & n.d. & - & n.d. & - \\
\hline$\gamma$-Nonalactone & 2008 & RI, MS & $50.7 \pm 35.4$ & $10.2-115.0$ & $21.5 \pm 21.2$ & $0.0-59.9$ & $37.8 \pm 23.0$ & $13.8-77.5$ \\
\hline$\gamma$-Decalactone & 2149 & RI, MS & $(55.8 \pm 51.7)^{\mathrm{a}}$ & $11.1-143.1$ & $(17.2 \pm 15.3)^{\mathrm{b}}$ & $0.0-38.2$ & n.d. & - \\
\hline$\gamma$-Undecalactone & 2206 & RI, MS & $49.8 \pm 29.4$ & $0.0-79.2$ & $25.3 \pm 9.9$ & $14.0-41.9$ & $19.2 \pm 22.0$ & $0.0-47.7$ \\
\hline \multicolumn{9}{|l|}{ Acetals } \\
\hline 2,4,5-Trimethyl-1,3-dioxolane & $<1000$ & RI, MS & $8.0 \pm 19.5$ & $0.0-47.7$ & n.d. & - & n.d. & - \\
\hline 1,1-Diethoxy-3-methylbutane & 1065 & RI, MS & $21.8 \pm 24.1$ & $0.0-53.8$ & n.d. & - & n.d. & - \\
\hline
\end{tabular}


Table 4. - continued

\begin{tabular}{|c|c|c|c|c|c|c|c|c|}
\hline \multirow{3}{*}{ Compound } & \multirow{3}{*}{ LRI } & \multirow{3}{*}{ ID } & \multicolumn{6}{|c|}{$\gamma /(\mu \mathrm{g} / \mathrm{L})$} \\
\hline & & & \multicolumn{2}{|c|}{ NMI } & \multicolumn{2}{|c|}{ SMI-1 } & \multicolumn{2}{|l|}{ SMI } \\
\hline & & & Mean value \pm S.D. & Range & Mean value \pm S.D. & Range & Mean value \pm S.D. & Range \\
\hline $\begin{array}{l}\text { 2-Cyclohexyl-4,5- } \\
\text { dimethyl-1,3-dioxolane I }\end{array}$ & 1091 & MS & $3.5 \pm 8.6$ & $0.0-21.0$ & n.d. & - & n.d. & - \\
\hline $\begin{array}{l}\text { 2-Cyclohexyl-4,5- } \\
\text { dimethyl-1,3-dioxolane II }\end{array}$ & 1151 & MS & $4.8 \pm 11.7$ & $0.0-28.7$ & n.d. & - & n.d. & - \\
\hline \multicolumn{9}{|l|}{ Sulphur compounds } \\
\hline $\begin{array}{l}\text { Dihydro-2-methyl-3(2H)- } \\
\text { thiophenone }\end{array}$ & 1510 & MS & n.d. & - & $25.2 \pm 18.3$ & $0.0-49.9$ & $38.2 \pm 17.9$ & $19.2-67.5$ \\
\hline Methionol & 1700 & RI, MS & $(114.3 \pm 53.2)^{\mathrm{a}}$ & $76.7-217.9$ & $(69.8 \pm 14.5)^{\mathrm{b}}$ & $46.9-86.5$ & $(67.5 \pm 14.4)^{\mathrm{b}}$ & $46.7-86.7$ \\
\hline
\end{tabular}

LRI=linear retention index; identification of compounds (ID): S=retention time and mass spectrum consistent with those of the pure standard and with NIST05 mass spectra electronic library, RI=retention index consistent with that found in literature, MS=mass spectra consistent with those from NIST05 mass spectra electronic library or literature. The compounds for which pure standards were not available (without symbol S in the ID column) were quantified semi-quantitatively, and their concentrations expressed as equivalents of compounds with similar chemical structure assuming a response factor of 1 .

Different superscript lowercase letters in a row present statistically significant differences between mean values at $p<0.05$ obtained by one-way ANOVA and least significant difference (LSD) test. TDN=1,1,6-trimethyl-1,2-dihydronaphthalene, TPB=trans-1-(2,3,6-trimethylphenyl)buta-1,3-diene, S.D.=standard deviation $(N=6)$, * concentrations expressed in $\mathrm{mg} / \mathrm{L}$

rels as a result of hydrolysis of their esters. The same authors hypothesized the possibility of the oxidative deamination of residual free amino acid precursors during maturation, so it is possible that additional quantities of higher alcohols in the wines produced by prolonged maceration and maturation were formed in the barrel and the bottle by the Ehrlich mechanism.

\section{Fatty acids}

Evidence exists that maceration and fermentation of unfiltered must may result in the inhibition of fatty acid biosynthesis in yeast cells, which consequently have to assimilate them directly from must, resulting in their lower concentrations in wine (36). Higher oxygen availability in wooden barrels slows down the release of middle-chain fatty acids from yeast cell walls $(6,37)$. A decrease in the concentration of straight-chain fatty acids during maturation was observed in several studies $(35,38)$. It was tentatively explained as a result of the action of residual microorganisms (39), while the possibility of acid-catalysed autoreduction to yield aldehydes has also been considered (28). All of the mentioned probably contributed to the significantly reduced straight-chain fatty acid content in the wines produced by prolonged maceration and maturation in relation to standard wines (Table 4).

\section{Volatile esters}

Significantly lower ester concentrations were found in the wines produced by prolonged maceration and maturation in comparison with the standard wines produced with or without maturation, except for ethyl acetate (Table 4). Evaporation due to higher temperatures, cap manipulation, and barrel porosity during fermentation and maceration could certainly have had a negative effect. Furthermore, the wines produced by prolonged maceration were in contact with lees, which have the ability to absorb esters (6), as well as to release esterases that hydrolyse them (40). During maturation, straight-chain esters hydrolyse $(35,41)$, which is most probably the main cause of their decrease in the wines produced by prolonged maceration and maturation. Higher concentration of ethyl acetate in these wines is in line with higher levels common for aged wines (35).

Within the group of the wines produced by prolonged maceration and maturation $(N=6)$, high positive correlation coefficients were found between the concentration of branched short-chain esters and the duration of maceration as well as maturation, ranging from 0.66 to 0.79 , and from 0.79 to 0.98 , respectively. The highest concentrations of ethyl lactate and diethyl succinate, the main malolactic fermentation esters, were found in these wines (Table 4). Esterification during maturation in order to reach equilibrium concentrations was probably the main cause.

Volatile phenols, benzenoids, furans, lactones and acetals

Higher level of ethylphenols and 4-propylphenol in the wines produced by prolonged maceration and maturation (Table 4) was probably a result of the activity of Brettanomyces and Dekkera yeast species which favour aerobic conditions during maturation in wood $(41,42)$. Besides that, it was previously found that the formation of ethylphenols positively correlates with maceration duration and temperature $(41,42)$. Among benzenoids, 2-ethoxybenzyl alcohol was found only in the wines produced by prolonged maceration and maturation (Table 4). Significantly higher concentration of furans in these wines (Table 4) is in agreement with previous findings, where furans were found to increase during maturation (35), which is favoured by the presence of lees and oxygen (6). The exclusive occurrence of the so-called oak lactones, together with the increased amounts of other identified lactones in the wines produced by prolonged maceration and maturation (Table 4), most probably originated from wood, as reported previously (42). Acetals are formed during fermentation, but their content increases most significantly during oxidative conditions of maturation 
$(35,42)$. In this work, four acetals were tentatively identified solely in these wines (Table 4). Among them, 2,4,5-trimethyl-1,3-dioxolane and 1,1-diethoxy-3-methylbutane have already been reported as important odourants in wines subjected to oxidation and in matured wines (42).

The impact of the key volatile aroma compounds

Aroma compounds with odour activity values (OAV) higher than 1, calculated on the basis of odour perception thresholds found in literature (43-47), and therefore with the direct impact on the aroma of the investigated wines, are listed in Table 5. Other compounds with OAV generally $<1$ are not presented.

Although fruity esters, such as ethyl octanoate and hexanoate, were the compounds with the strongest impact in all the investigated groups of wines, their OAVs were much higher in standard wine samples. In fact, these wines were characterised by a typical aroma profile of young white wines dominated by fruity esters and fatty acids, complemented by a significant contribution of $\beta$-damascenone, which corresponds to previous findings on Malvazija istarska wines (26). Besides a notable impact of straight-chain esters and $\beta$-damascenone, the most influential odourants in the wines produced by prolonged maceration and maturation were the compounds that originate from wood (lactones and eugenol), compounds often associated with fermentative maceration (higher alcohols, linalool), compounds mostly or exclusively generated by species other than yeasts (ethyl acetate, 4-ethylguaiacol, ethyl lactate) or in (semi)aerobic conditions and at higher temperatures (ethyl acetate, ethyl 3-methylbutyrate, isoamyl alcohol), as well as compounds whose concentration typically increases with ageing (ethyl acetate, ethyl 3-methylbutyrate, isoamyl alcohol, TDN, ethyl lactate). The aroma of the wines produced by prolonged maceration and maturation could be less intense due to

Table 5. Odour perception thresholds, odour descriptions, and odour activity values (OAV) of the key volatile aroma compounds in Malvazija istarska wines produced by prolonged maceration during and after fermentation followed by maturation in wooden barrels (NMI), standard white wine production technology followed by maturation in bottle for one year (SMI-1), and standard white wine production technology without maturation (SMI)

\begin{tabular}{|c|c|c|c|c|c|}
\hline \multirow[t]{2}{*}{ Compound } & \multirow{2}{*}{$\begin{array}{c}\begin{array}{c}\text { Odour perception } \\
\text { threshold }\end{array} \\
\mu \mathrm{g} / \mathrm{L}\end{array}$} & \multirow{2}{*}{ Odour description } & \multicolumn{3}{|c|}{ OAV } \\
\hline & & & NMI & SMI-1 & SMI \\
\hline \multicolumn{6}{|c|}{ More characteristic of NMI wines* } \\
\hline cis-Oak lactone & $35^{\mathrm{e}}$ & coconut, burnt wood & $17.3 \pm 17.7$ & - & - \\
\hline 4-Ethylguaiacol & $33^{\mathrm{d}}$ & toasted bread, smoky, clove & $13.5 \pm 11.9$ & $0.1 \pm 0.1$ & $0.2 \pm 0.5$ \\
\hline Ethyl acetate & $7500^{c}$ & varnish, fruity & $10.0 \pm 1.1$ & $4.6 \pm 0.7$ & $6.0 \pm 0.9$ \\
\hline Ethyl 3-methylbutyrate & $3^{\mathrm{d}}$ & berry, blackberry & $9.7 \pm 5.7$ & $3.0 \pm 0.9$ & $1.4 \pm 0.1$ \\
\hline Isoamyl alcohol & $30000^{\mathrm{d}}$ & solvent, alcoholic & $8.1 \pm 1.3$ & $5.3 \pm 0.9$ & $5.0 \pm 0.6$ \\
\hline TDN & $2^{\mathrm{b}}$ & petrol, kerosene & $6.0 \pm 7.3$ & $1.6 \pm 1.5$ & $0.9 \pm 0.4$ \\
\hline 2-Phenylethanol & $10000^{c}$ & rose & $4.0 \pm 1.1$ & $2.6 \pm 0.8$ & $1.7 \pm 0.4$ \\
\hline Linalool & $15^{\mathrm{a}}$ & floral, rose, sweet & $2.5 \pm 1.6$ & $1.4 \pm 0.3$ & $1.0 \pm 0.3$ \\
\hline Eugenol & $6^{d}$ & cloves, cinnamon & $2.2 \pm 2.0$ & - & - \\
\hline$\gamma$-Nonalactone & $30^{\mathrm{d}}$ & coconut & $1.7 \pm 1.2$ & $0.7 \pm 0.7$ & $1.3 \pm 0.8$ \\
\hline Ethyl lactate & $100000^{c}$ & buttery & $1.4 \pm 0.4$ & $0.2 \pm 0.1$ & $0.1 \pm 0.1$ \\
\hline trans-Oak lactone & $122^{\mathrm{e}}$ & coconut, burnt wood & $1.4 \pm 0.9$ & - & - \\
\hline \multicolumn{6}{|c|}{ More characteristic of SMI wines } \\
\hline Ethyl octanoate & $2^{\mathrm{c}}$ & fruity, soapy & $64.0 \pm 47.1$ & $402.4 \pm 111.4$ & $595.7 \pm 134.9$ \\
\hline Ethyl hexanoate & $5^{c}$ & fruity, green apple & $29.1 \pm 16.9$ & $109.3 \pm 16.1$ & $133.7 \pm 27.0$ \\
\hline Isoamyl acetate & $30^{\mathrm{d}}$ & banana & $4.0 \pm 3.7$ & $60.3 \pm 11.3$ & $129.3 \pm 47.0$ \\
\hline$\beta$-Damascenone & $0.05^{\mathrm{a}}$ & stewed apple, dried plum, honey, lilac & $27.0 \pm 17.4$ & $29.0 \pm 4.6$ & $47.0 \pm 12.0$ \\
\hline Ethyl butyrate & $20^{\mathrm{d}}$ & banana, pineapple & $7.1 \pm 3.1$ & $21.8 \pm 3.7$ & $26.8 \pm 4.9$ \\
\hline Hexanoic acid & $420^{\mathrm{d}}$ & cheese, fatty, rancid & $2.6 \pm 1.1$ & $13.7 \pm 3.8$ & $12.2 \pm 3.6$ \\
\hline Octanoic acid & $500^{d}$ & fatty, rancid & $1.4 \pm 1.1$ & $12.4 \pm 2.4$ & $10.6 \pm 2.2$ \\
\hline Butyric acid & $173^{\mathrm{d}}$ & cheese, fatty, rancid & $5.1 \pm 1.2$ & $12.3 \pm 3.1$ & $10.3 \pm 1.9$ \\
\hline 2-Phenethyl acetate & $250^{\mathrm{d}}$ & flowery, rose & $0.6 \pm 0.3$ & $5.3 \pm 0.2$ & $7.9 \pm 1.5$ \\
\hline Ethyl decanoate & $200^{c}$ & fruity, soapy & $0.4 \pm 0.3$ & $2.5 \pm 0.9$ & $3.6 \pm 0.8$ \\
\hline Decanoic acid & $1000^{\mathrm{d}}$ & fatty, rancid & $0.1 \pm 0.0$ & $1.0 \pm 0.5$ & $1.7 \pm 0.7$ \\
\hline
\end{tabular}

OAV values are expressed as mean \pm standard deviation $(N=6)$, TDN=1,1,6-trimethyl-1,2-dihydronaphthalene

*Compounds more characteristic of NMI wines are listed in a decreasing order of the mean OAV values in NMI wines, while compounds more characteristic of SMI wines are listed in a decreasing order of the mean OAV values in SMI wines

Odour detection thresholds from references: ${ }^{\mathrm{a}}(43), \mathrm{b}(44),{ }^{\mathrm{c}}(45),{ }^{\mathrm{d}}(46),{ }^{\mathrm{e}}(47)$ 
lower OAVs in general (Table 5). However, judging by the odour descriptors of the key components which introduced certain atypical nuances into the aroma profile of Malvazija istarska (Table 5), it is probably more complex than that of standard wines.

\section{Conclusions}

The present investigation showed that the application of an unconventional combination of oenological practices in the production of white wines, including prolonged maceration during and after fermentation followed by maturation in wooden barrels, results in unusual composition, which in all probability strongly reflects on their sensory properties. Such wines exhibited elevated levels of dry extract, volatile acidity, lactic acid and phenols, as well as higher colour intensities when compared to standard wines. In contrast to a typical aroma profile of young white wines dominated by fruity esters, unconventional wines contained increased concentrations of the majority of monoterpenes, $\mathrm{C}_{13}$-norisoprenoids, methanol, higher alcohols, ethyl acetate, branched ethyl esters and esters from hydroxy and dicarboxylic acids, ethylphenols, furans, and acetals, while the content of straight-chain ethyl and acetate esters was drastically reduced. In a number of aspects, the composition of such wines resembled that of aged red wine. Besides the measured drift in colour intensity at $420 \mathrm{~nm}$, possible repercussions on their organoleptic characteristics might include milder acidity due to the replacement of malic with lactic acid, fuller body with more intense bitterness and astringency originating from the increased levels of phenols, and a less pronounced but more complex aroma, which should all be confirmed by detailed and systematic sensory evaluation in further research. Judging by analogy with the existing knowledge, it can be roughly stated that maceration had a major impact on phenols, while volatile aromas were more significantly altered by maturation. The unconventional wine samples showed a solid level of homogeneity in the composition representing a distinctive wine type, despite different vintages and technological details. Accentuated antioxidant activity found offers the possibility to raise awareness about their value in a nutritional sense, and develop new marketing strategies until now mainly reserved for red wines.

\section{References}

1. Darias-Martín JJ, Rodríguez O, Díaz E, Lamuela-Raventós RM. Effect of skin contact on the antioxidant phenolics in white wine. Food Chem. 2000;71:483-7. http://dx.doi.org/10.1016/S0308-8146(00)00177-1

2. Selli S, Cabaroglu T, Canbas A, Erten H, Nurgel C. Effect of skin contact on the aroma composition of the musts of Vitis vinifera L. cv. Muscat of Bornova and Narince grown in Turkey. Food Chem. 2003;81:341-7. http://dx.doi.org/10.1016/S0308-8146(02)00428-4

3. Gómez-Míguez MJ, González-Miret ML, Hernanz D, Fernández MA, Vicario IM, Heredia FJ. Effects of prefermentative skin contact conditions on colour and phenolic content of white wines. J Food Eng. 2007;78:238-45. http://dx.doi.org/10.1016/j.jfoodeng.2005.09.021

4. Radeka S, Herjavec S, Peršurić Đ, Lukić I, Sladonja B. Effect of different maceration treatments on free and bound vari- etal aroma compounds in wine of Vitis vinifera L. cv. Malvazija istarska bijela. Food Technol Biotechnol. 2008;46:86-92.

5. Di Maro E, Ercolini D, Coppola S. Yeast dynamics during spontaneous wine fermentation of the Catalanesca grape. Int J Food Microbiol. 2007;117:201-10. http://dx.doi.org/10.1016/j.ijfoodmicro.2007.04.007

6. Liberatore MT, Pati S, Del Nobile MA, La Notte E. Aroma quality improvement of Chardonnay white wine by fermentation and ageing in barrique on lees. Food Res Int. 2010;43: 996-1002.

http://dx.doi.org/10.1016/j.foodres.2010.01.007

7. Lomolino G, Zocca F, Spettoli P, Zanin G, Lante A. A preliminary study on changes in phenolic content during Bianchetta Trevigiana winemaking. J Food Comp Anal. 2010;23:575-9. http://dx.doi.org/10.1016/j.jfca.2010.04.001

8. Baiano A, Varva G, De Gianni A, Viggiani I, Terracone C, Del Nobile MA. Influence of type of amphora on physico-chemical properties and antioxidant capacity of 'Falanghina' white wines. Food Chem. 2014;146:226-33.

http://dx.doi.org/10.1016/j.foodchem.2013.09.069

9. Díaz C, Laurie VF, Molina AM, Bücking M, Fischer R. Characterization of selected organic and mineral components of qvevri wines. Am J Enol Vitic. 2013;64:532-7. http://dx.doi.org/10.5344/ajev.2013.13027

10. Ribérau-Gayon P, Glories Y, Maujean A, Dubourdieu D, editors. Handbook of enology: The chemistry of wine - stabilization and treatments, vol. 2. Chichester, UK: John Wiley \& Sons Ltd.; 2000.

http://dx.doi.org/10.1002/0470010398

11. Bavčar D, Baša Češnik H, Čuš F, Vanzo A, Gašperlin L, Košmerl T. Impact of alternative skin contact procedures on the aroma composition of white wine. S Afr J Enol Vitic. 2011; 32:190-203.

12. Di Lecce G, Boselli E, D’Ignazi G, Frega NG. Evolution of phenolics and glutathione in Verdicchio wine obtained with maceration under reductive conditions. LWT - Food Sci Technol. 2013;53:54-60.

http://dx.doi.org/10.1016/j.lwt.2013.03.006

13. EEC Regulation No. 2676/90. Community methods for the analysis of wine. Off J. 1990;L272:1-192.

14. Di Stefano R, Cravero MC, Gentilizi N. Methods of determination of polyphenols in wine. L'Enotecnico. 1989;5:83-9 (in Italian).

15. Brand-Williams W, Cuvelier ME, Berset C. Use of a free radical method to evaluate antioxidant activity. LWT - Food Sci Technol. 1995;28:25-30. http://dx.doi.org/10.1016/S0023-6438(95)80008-5

16. Noguerol-Pato R, González-Barreiro C, Cancho-Grande B, Simal-Gándara J. Quantitative determination and characterisation of the main odourants of Mencía monovarietal red wines. Food Chem. 2009;117:473-84. http://dx.doi.org/10.1016/j.foodchem.2009.04.014

17. Kovačević Ganić K, Peršurić Đ, Komes D, Dragović-Uzelac V, Banović M, Piljac J. Antioxidant activity of Malvasia istriana grape juice and wine. Ital J Food Sci. 2006;18:187-97.

18. Recamales AF, Sayago A, González-Miret ML, Hernanz D. The effect of time and storage conditions on the phenolic composition and colour of white wine. Food Res Int. 2006; 39:220-9.

http://dx.doi.org/10.1016/j.foodres.2005.07.009

19. Ružić I, Škerget M, Knez Ž, Runje M. Phenolic content and antioxidant potential of macerated white wines. Eur Food Res Technol. 2011;233:465-72. http://dx.doi.org/10.1007/s00217-011-1535-4

20. Hernández-Jiménez A, Kennedy JA, Bautista-Ortín AB, Gómez-Plaza E. Effect of ethanol on grape seed proanthocyani- 
din extraction. Am J Enol Vitic. 2012;63:57-61.

http://dx.doi.org/10.5344/ajev.2011.11053

21. Hernanz D, Gallo V, Recamales ÁF, Meléndez-Marténez AJ, González-Miret ML, Heredia, FJ. Effect of storage on the phenolic content, volatile composition and colour of white wines from the varieties Zalema and Colombard, Food Chem. 2009;113:530-7. http://dx.doi.org/10.1016/j.foodchem.2008.07.096

22. Ortega AF, Lopez-Toledano A, Mayen M, Merida J, Medina M. Changes in color and phenolic compounds during oxidative aging of sherry white wine. J Food Sci. 2003;68:2461-8. http://dx.doi.org/10.1111/j.1365-2621.2003.tb07046.x

23. Ortega AF, Mayen M, Medina M. Study of colour and phenolic compounds in two models of oxidative ageing for sherry type white wines. Food Control. 2008;19:949-56. http://dx.doi.org/10.1016/j.foodcont.2007.09.008

24. Hernanz D, Recamales ÁF, González-Miret ML, Gomez-Miguez MJ, Vicario IM, Heredia FJ. Phenolic composition of white wines with a prefermentative maceration at experimental and industrial scale. J Food Eng. 2007;80:327-35. http://dx.doi.org/10.1016/j.jfoodeng.2006.06.006

25. Stratil P, Kubáň V, Fojtová J. Comparison of the phenolic content and total antioxidant activity in wines as determined by spectrophotometric methods. Czech J Food Sci. 2008;26: 242-53.

26. Lukić I, Plavša T, Sladonja B, Radeka S, Peršurić Đ. Aroma compounds as markers of wine quality in the case of Malvazija istarska young wine. J Food Quality. 2008;31:717-35. http://dx.doi.org/10.1111/j.1745-4557.2008.00230.x

27. Zoecklein BW, Marcy JE, Jasinski Y. Effect of fermentation, storage sur lie or post-fermentation thermal processing on White Riesling (Vitis vinifera L.) glycoconjugates. Am J Enol Vitic. 1997:48;397-402.

28. Ferreira V, Escudero A, Fernández P, Cacho JF. Changes in the profile of volatile compounds in wines stored under oxygen and their relationship with the browning process. Z Lebensm Unters Forsch A. 1997;205:392-6. http://dx.doi.org/10.1007/s002170050187

29. Oliveira JM, Oliveira P, Baumes RL, Maia O. Changes in aromatic characteristics of Loureiro and Alvarinho wines during maturation. J Food Compos Anal. 2008;21:695-707. http://dx.doi.org/10.1016/j.jfca.2008.08.002

30. Marais J. Terpene concentrations and wine quality of Vitis vinifera L. cv. Gewurtztraminer as affected by grape maturity and cellar practices. Vitis. 1987;26:231-45.

31. Loscos N, Hernández-Orte P, Cacho J, Ferreira V. Evolution of the aroma composition of wines supplemented with grape flavor precursors from different varietals during accelerated wine ageing. Food Chem. 2010;120:205-16. http://dx.doi.org/10.1016/j.foodchem.2009.10.008

32. Silva Ferreira AC, de Pinho PG. Nor-isoprenoids profile during port wine ageing - influence of some technological parameters. Anal Chim Acta. 2004;513:169-76. http://dx.doi.org/10.1016/j.aca.2003.12.027

33. OIV-MA-C1-01: R2011. Maximum acceptable limits of various substances contained in wine. Compendium of International Methods of Analysis of Wines and Must. International Organization of Vine and Wine (OIV); 2011.

34. Vidrih R, Hribar J. Synthesis of higher alcohols during cider processing. Food Chem. 1999;67:287-94. http://dx.doi.org/10.1016/S0308-8146(99)00136-3

35. Câmara JS, Alves MA, Marques JC. Changes in volatile composition of Madeira wines during their oxidative ageing.
Anal Chim Acta. 2006;563:188-97.

http://dx.doi.org/10.1016/j.aca.2005.10.031

36. Valero E, Millán C, Ortega JM. Influence of pre-fermentative treatment on the fatty acid content of Saccharomyces cerevisiae (M330-9) during alcoholic fermentation of grape must. J Biosci Bioeng. 2001;91:117-22.

http://dx.doi.org/10.1016/S1389-1723(01)80052-9

37. Torija MJ, Beltran G, Novo M, Poblet M, Guillamón JM, Mas A, Rozès N. Effects of fermentation temperature and Saccharomyces species on the cell fatty acid composition and presence of volatile compounds in wine. Int J Food Microbiol. 2003;85:127-36.

http://dx.doi.org/10.1016/S0168-1605(02)00506-8

38. Hernández-Orte P, Lapeña AC, Escudero A, Astrain J, Baron C, Pardo I, et al. Effect of micro-oxygenation on the evolution of aromatic compounds in wines: malolactic fermentation and ageing in wood. LWT - Food Sci Technol. 2009;42:391401.

http://dx.doi.org/10.1016/j.lwt.2008.05.020

39. Ancín C, Ayestarán B, García A, Garrido J. Evolution of fatty acid contents in Garnacha and Viura musts during fermentation and the aging of wine. $\mathrm{Z}$ Lebensm Unters Forsch A. 1998;206:144-7. http://dx.doi.org/10.1007/s002170050230

40. Ancín-Azpilicueta C, González-Marco A, Jiménez-Moreno $\mathrm{N}$. Evolution of esters in aged Chardonnay wines obtained with different vinification methods. J Sci Food Agric. 2009;89: 2446-51. http://dx.doi.org/10.1002/jsfa.3744

41. Garde Cerdán T, Rodríguez Mozaz S, Ancín Azpilicueta C. Volatile composition of aged wine in used barrels of French oak and of American oak. Food Res Int. 2002;35:603-10. http://dx.doi.org/10.1016/S0963-9969(01)00151-X

42. Perestrelo R, Barros AS, Câmara JS, Rocha SM. In-depth search focused on furans, lactones, volatile phenols, and acetals as potential age markers of Madeira wines by comprehensive two-dimensional gas chromatography with time-of-flight mass spectrometry combined with solid phase microextraction. J Agric Food Chem. 2011;59:3186-204. http://dx.doi.org/10.1021/jf104219t

43. Guth H. Quantitation and sensory studies of character impact odorants of different white wine varieties. J Agric Food Chem. 1997;45:3027-32. http://dx.doi.org/10.1021/jf970280a

44. Sacks GL, Gates MJ, Ferry FX, Lavin EH, Kurtz AJ, Acree TE. Sensory threshold of 1,1,6-trimethyl-1,2-dihydronaphthalene (TDN) and concentrations in young Riesling and nonRiesling wines. J Agric Food Chem. 2012;60:2998-3004. http://dx.doi.org/10.1021/jf205203b

45. Moreno JA, Zea L, Moyano L, Medina M. Aroma compounds as markers of the changes in sherry wines subjected to biological ageing. Food Control 2005;16:333-8. http://dx.doi.org/10.1016/j.foodcont.2004.03.013

46. Ferreira V, López R, Cacho JF. Quantitative determination of the odorants of young red wines from different grape varieties. J Sci Food Agric. 2000;80:1659-67. http://dx.doi.org/10.1002/1097-0010(20000901)80:11<1659: :AID-JSFA693>3.0.CO;2-6

47. Zea L, Moyano L, Moreno JA, Medina M. Aroma series as fingerprints for biological ageing in fino sherry-type wines. J Sci Food Agric. 2007;87:2319-26. http://dx.doi.org/10.1002/jsfa.2992 